\title{
Rent-seeking and timber rights allocation in Ghana
}

Carlsen, Kirsten; Hansen, Christian Pilegaard

Published in:

International Forestry Review

DOI:

$10.1505 / 146554814814095375$

Publication date:

2014

Document version

Publisher's PDF, also known as Version of record

Citation for published version (APA):

Carlsen, K., \& Hansen, C. P. (2014). Rent-seeking and timber rights allocation in Ghana. International Forestry Review, 16(6), 537-548. https://doi.org/10.1505/146554814814095375 


\title{
Rent-seeking and timber rights allocation in Ghana
}

\author{
K. CARLSEN ${ }^{1}$ and C.P. HANSEN ${ }^{2}$ \\ ${ }^{1}$ Department of Geosciences and Natural Resource Management, Faculty of Science, University of Copenhagen \\ ${ }^{2}$ Department of Food and Resource Economics, Faculty of Science, University of Copenhagen
}

Email: kica@ign.ku.dk, cph@ifro.ku.dk

\section{SUMMARY}

This paper describes types, processes and importance of rent-seeking in the allocation of timber rights in Ghana. It is based on an analysis of 30 interviews with large-, medium- and small-scale timber firms, as well as government officials and timber industry organizations in Ghana. The paper documents that timber rights allocation is associated with both bureaucratic and political corruption. The latter comes in two forms. First, the findings suggest that well-established relationships exist between politicians and senior bureaucrats on the one side and large-scale timber firms on the other involving exchange of timber rights for political support and/or material, personal benefits. Second, timber rights are allocated to persons or firms outside the timber sector allegedly as payment for political support. The paper concludes that the Voluntary Partnership Agreement between Ghana and the EU is likely to reduce the observed practises in the future through increased transparency.

Keywords: Bureaucratic corruption, political corruption, lobbying, competitive bidding, Forest Law Enforcement, Governance and Trade (FLEGT)

\section{Recherche de location de terre et allocation de droits au bois au Ghana

\author{
K. CARLSEN et C.P. HANSEN
}

Cet article décrit les types, les processus et l'importance de la recherche de location de terre dans l'allocation de droits au bois au Ghana. Il se base sur une analyse de 30 interviews avec des firmes de bois de grande à petite échelle, ainsi qu'avec des personnages officiels du gouvernement et avec des organisations industrielles au Ghana. Cet article montre que l'allocation de droits au bois est associée à une corruption tout à la fois bureaucratique et politique. La corruption politique s'effectue de deux façons. Les découvertes montrent tout d'abord, que des relations bien établies existent entre les politiciens et les bureaucrates supérieurs d'un côté et les firmes de bois à grande échelle d'un autre côté, incluant des échanges de droits au bois avec un support politique ou des bénéfices personnels matériels. Elles montrent ensuite que les droits au bois sont accordés à des personnes ou des firmes extérieures au secteur du bois, il semblerait en tant que paiement pour un support politique. L'article conclut que l'Accord de partenariat volontaire entre le Ghana et l'Union Européènne va probablement réduire les pratiques observées dans le futur grâce à une transparence accrue.

\section{La captación de rentas y la asignación de derechos madereros en Ghana}

\section{K. CARLSEN y C.P. HANSEN}

Este artículo describe los tipos, procesos e importancia de la captación de rentas en la asignación de derechos madereros en Ghana, a partir de un análisis de 30 entrevistas a empresas de grande, mediana y pequeña escala, así como a funcionarios del gobierno y organizaciones de la industria de la madera de Ghana. El artículo documenta cómo la asignación de derechos sobre la madera está ligada a la corrupción burocrática y política. Esta última se presenta en dos formas. En primer lugar, los resultados sugieren la existencia de relaciones bien establecidas entre los políticos y burócratas de alto nivel, por un lado, y las empresas madereras a gran escala, por el otro, en cuanto a la concesión de derechos maderables a cambio de apoyo político o favores materiales o personales. En segundo lugar, se asignan derechos maderables a personas o empresas que no forman parte del sector de la madera, supuestamente como pago por el apoyo político. El artículo concluye que es probable que el Acuerdo Voluntario de Asociación entre Ghana y la UE reduzca en el futuro este comportamiento observado gracias a una mayor transparencia. 


\section{INTRODUCTION}

Rent-seeking - in the form of bureaucratic and political corruption, and lobbying - has been put forward as a prominent explanation for the apparent failure of resource rich states to transform such wealth into societal development and sustained economic growth (Broad 1995, Collier 2008, Kolstad and Søreide 2009, Ross 2001). It is argued that rent-seeking brings about policies that favour the interests of powerful actors rather than those of the general public and that it distracts the implementation of policy and dilutes legal and regulatory enforcement (Jain 2001, Khan and Sundaram 2000, Lambsdorff 2008, Scott 1972). There is a host of studies addressing rent-seeking through modelling or try to correlate policy outcomes with corruption perception indexes, see review in e.g. Lambsdorff (2008), but there are fewer studies that address rent-seeking empirically. In response, this paper attempts an empirically based description and analysis of rent-seeking practises in connection with allocation of timber rights in Ghana. The specific purpose is to describe types, processes and importance of rent-seeking in the allocation of timber rights in Ghana. The paper is based on an analysis of 30 interviews with large-, medium- and small-scale timber firms, as well as government officials and timber industry organizations in Ghana.

The paper proceeds as follows. The next section briefly reviews the different types of rent-seeking described in the literature with particular focus on sources that discuss rent-seeking in natural resource sectors and in developing countries. It is followed by a brief background section summarizing the legal framework and history of timber right allocation in Ghana. Next, sampling strategy and methods for data collection and analysis are described followed by presentation of the result. A discussion section and a brief concluding section complete the paper.

\section{RENT-SEEKING}

A rent is typically defined as an income "higher than the minimum which an individual or firm would have accepted given alternative opportunities" (Khan and Sundaram 2000: 5). A rent is thus a surplus in the economy which various actors may seek to acquire through different types of rent-seeking activities. These activities are typically regarded as costly for society as resources put into rent-seeking could have alternative, more productive uses (Kolstad and Søreide 2009, Schleifer and Vishny 1993). Rent-seeking is thus often defined as the "socially costly pursuit of rents" (Svensson 2005: 21), i.e. a cost. This paper applies an alternative definition of rent-seeking as "activities which seek to create, maintain or change the rights and institutions on which particular rents are based" (Khan and Sundaram 2000: 5). This definition is concerned with the processes between social actors rather than the cost. For purpose of structure, these processes are here grouped into bureaucratic corruption, political corruption and lobbying.

\section{Bureaucratic corruption}

Corruption is commonly defined as "the misuse of public power for private benefit" (Lambsdorff 2008: 16). Bureaucratic (or petty) corruption involves a bureaucrat (the agent/ bribee) entrusted with power to implement a set of rules and a client (the briber) (Fjeldstad and Isaksen 2008, Lambsdorff 2008). From an economist's point of view the incentive for the bureaucrat to engage in corruption is personal gain and the bureaucrat may engage in corrupt activities as long as the perceived costs of being detected and punished are lower than the perceived benefits (Schleifer and Vishny 1993). Other scholars of corruption emphasize that the bureaucrat is embedded in a social network and daily life practises with obligations, traditions and norms which shape behaviour of both the bureaucrat and the briber, i.e. not only perceived costs and benefits shape behavior (Blundo et al. 2006).

Corruption may be collusive or non-collusive. In the latter case, the bureaucrat demands a payment in excess of what is otherwise required, for example, when the bureaucrat demands a bribe for a service which the client is entitled to for free. Non-collusive corruption does not change rule compliance, but increases the costs of the client. The client thus has an incentive to report the bribee and to support efforts that may change the practice. In collusive corruption, the interaction is mutually beneficial to the bribee and briber, e.g. by providing the agent/briber with services or permits that he/she would otherwise not be entitled to. The costs of the client are reduced (or benefits increased) while the bribee benefits through the bribe. Here, the parties are less likely to be support a change of practice (Bardhan 1997, Kolstad and Wiig 2009, Smith et al. 2003).

Bureaucratic corruption (when collusive) leads to violation of rules and thus hinders implementation of policies aiming at changing behaviour of targeted actors (Kolstad and Søreide 2009, Lambsdorff 2008, Svensson 2005). Bureaucratic corruption may also encourage bureaucrats to engage in the creation of additional or more complex administrative procedures that provide them with additional discretionary powers which give opportunities for bribes (Khan and Sundaram 2000, Lambsdorff 2008).

\section{Political corruption}

Political corruption involves politicians, ministers and senior bureaucrats as the agent (bribee) on the one side and a client (briber) on the other (Lambsdorff 2008, Ross 2001, Scott 1969). It can be described as the "abuse of office by those who make the game, e.g. decide on laws and regulations, and the allocation of resources in a society" (Fjeldstad and Isaksen 2008: 6). It is thus considered as political corruption when politicians and ministers shape laws and regulations to the advantage of selected private sector actors or grant public contracts to specific firms in return for bribes or other types of favours. It follows that political corruption is less straightforward than bureaucratic corruption and involves a normative element because the activity may not be against the legal framework (de facto illegal), but rather the "public interest" 
(Lambsdorff 2008). The literature on political corruption thus concerns the broader question of the nature of the state and the motives of politicians and high ranking civil servants. Some scholars see political corruption as an integrated part of ruling elites' pursuit of personal gains and political power through extensive and long-established patron-client relations (Bates 1981, Bayart 2009). In relation to natural resources, Ross (2001) emphasizes those processes that give politicians or senior bureaucrats direct, exclusive and discretionary control over resource allocation processes, the fiscal regime (royalties, export fees etc.) and market access. He terms this process rent seizing. Such control allows the establishment of long-term relationships between politicians and senior bureaucrats on the one side and their clients on the other where the provision of rent opportunities e.g. in the form of resource rights are provided in exchange of personal/political favours, in cash or kind (Ross 2001). Such relations make market entry of new actors more difficult than under more competitive conditions and they discourage new and more efficient investments in the affected resource sectors. The reciprocal nature of the relationship is likely to motivate both sides to fiercely resist reform efforts with the potential to disrupt the status quo (Khan and Sundaram 2000, Lambsdorff 2008, Ross 2001).

On the relationship between bureaucratic and political corruption, Lambsdorff (2008) argues that political corruption is likely to restrict the occurrence of bureaucratic corruption, because the latter reduces rents available at the political level. Other scholars, however, suggest that political corruption with no bureaucratic corruption is rare, because the contagious nature of political corruption makes lower level bureaucrats to adapt the "predatory" example of their principals (Fjeldstad and Isaksen 2008). Allowing lower level bureaucrats to take bribes and perhaps even enacting ambiguous regulation which enhances the opportunities for bribes, may even be seen as a way for high-level State officials to ensure loyalty of lower level employees. This may be important, e.g. when policies linked to political corruption require close participation of the bureaucratic level (Lipsky 2010, Scott 1972, Winther and Nielsen 2010).

\section{Lobbying}

The lobbying perspective asserts that actors cannot always achieve their self-interest individually, and hence engage in group action (Grindle 1989, Hackett 2001). Lobbying (sometimes also termed regulatory capture) may be defined as "processes through which special interests affect state intervention in any of its forms" (Bó 2006: 203). It may determine the concerns that reach the policy agenda and how the policies addressing these concerns will be formulated (Bó 2006). Lobbying asserts that interest groups attempt to influence politicians and bureaucrats through means such as information dissemination and public campaigns. It may also involve various forms of incentives for the politicians such as campaign contributions or the promise of future, lucrative employment (the revolving door phenomenon) (Agrell and Gautier 2012, Bó 2006, Hackett 2001). Lobbying may also involve negative incentives such as threats of spreading rumours and, in extreme cases, physical violence (Bó 2006). It is normally distinguished from political and bureaucratic corruption in that it does not involve bribes. It is, however, difficult to draw a clear distinction between lobbying and corruption.

Lobbying is by some scholars regarded as a process of more or less full competition between interest groups, where the policy decision maker is responding more or less passively to the pressure of the strongest group (Stigler 1971). Others regard lobbying as a process where policy decision makers are actively pursuing private aims, e.g. to stay in office or future job opportunities (Boehm 2007), i.e. some form of intersect between political corruption and lobbying. Here, the relationship between decision makers and interest groups becomes more collusive and the resistance to change current practices is likely to be more prominent.

It is argued that under conditions of weak institutions (lacking rule of law), it makes little sense for organized interests to attempt to influence the policy formulation process because decision-making activities tend to be disaggregated, personalized and particularistic and targeted at the stages of implementation rather than at the stages of agenda setting and policy formulation (Scott 1972, Grindle 1989). "Even though interest groups exist, businessmen in developing countries may realize that the administration of even the most favourable tax laws will have little or no resemblance of what is called for in the statutes. That is, they may have to bribe as much to secure enforcement of a favourable law as to escape the provisions of an unfavourable one. Under these circumstances, then, it may make more sense for each enterprise to quietly "buy" precisely what it needs in term of enforcement or non-enforcement, rather than to finance an open campaign for a new law that would be as formalistic as the existing one" (Scott 1972: 24-5). Accordingly, extensive organized interest group activity tends to be less clearly defined and observable in areas with weak or absent government institutions (Grindle 1989).

\section{TIMBER RIGHTS ALLOCATION IN GHANA}

The timber resources ${ }^{1}$ are located in the Southern part of Ghana, the High Forest Zone. The zone covers approximately 8 million ha of which 1.8 million ha are gazetted as forest reserve, i.e. a permanent forest estate. Outside the reserves there are few remaining forest patches, but many scattered trees in an agricultural landscape dominated by perennial crops, mainly cocoa. The forests and trees are owned communally by the local communities (the Stools), which are

1 The large majority of timber in Ghana originates from natural forests and "natural" trees nurtured by farmers on their farms. Plantation forestry in still in its infancy, and the annual rate of plantation establishment is low, probably around 15,000 ha annually (Oduro et al. 2014). 
headed by chiefs (Aryeetey et al. 2007, Boni 2005, Kasanga and Kotey 2001). Traditionally, the chiefs could negotiate agreements with individuals or firms on timber rights in return for payments, cash or material, to the Stool (Amanor 1996). Following Ghana's independence in 1957, the new government enacted the Concessions Act vesting all timber resources in the President in trust for the Stools (GoG 1962). This implies that the central government is in charge of (i) the allocation of timber rights to private firms; (ii) the formulation and enforcement of the rules governing timber extraction; and (iii) the collection of fees from the timber firms (Hansen and Lund 2011). The accruing revenues are distributed between the Stools, Traditional Councils, District Assemblies (local government) and the Forestry Commission of Ghana (FC) according to a sharing arrangement stipulated in the Constitution of Ghana (GoG 1992).

In 1994, Ghana adopted a Forest and Wildlife Policy. The policy, among other things, called for competitive bidding in allocation of timber rights. This was done in order to "eliminate unnecessary speculations" and have fees to ". . .reflect the economic value of the resource and to recover optimum revenues for supporting the cost of sustainable resource management and development" (GoG 1994: 5.3.6 and 5.4.3). A number of legislative changes on timber rights allocation followed in the years after the adoption of the policy (Table 1).

The 1997 Timber Resources Management Act (TRMA) and the 1998 Timber Resources Management Regulations (TRMR) did not introduce competitive bidding (as the policy had stipulated) but instead revised the types of timber rights that could be allocated and the administrative procedures. Timber Utilization Contracts (TUCs) were introduced as the only valid type of timber right for commercial purposes. All previous concessions and leases were to be converted to TUCs within 6 months. Detailed application procedures and award criteria were put in place under a newly established Timber
Rights Evaluation Committee (TREC). Based on the recommendation of TREC, and upon approval by the Parliament, the Minister of Land and Natural Resources was to award TUCs on behalf of the President (GoG1997). TUCs were of 40 years duration. Further, the Chief Conservator of Forest (now Chief Executive of the Forestry Commission) was granted authority to issue 5 years Timber Utilization Permits (TUPs) to District Assemblies, Town Committees, rural community groups and NGOs after application. TUPs were to be issued exclusively for the harvest of a specified number of timber trees for social and community purposes. Another type of permits, Salvage Felling Permits (SFPs), was meant for salvage of trees on land undergoing development like road construction, expansion of human settlements or farms (GoG 1998).

After pressure from the World Bank and the International Monetary Fund, who conditioned recapitalization of old debts to the enactment of competitive bidding for timber rights, the 2002 Timber Resources Management (Amendment) Act and the 2003 Timber Resource Management (Amendment) Regulations paved the way for introduction of competitive bidding for natural timber resources. TREC was to publicly advertise invitations for pre-qualified applicants to bid for timber rights to specific areas. The timber right is awarded to the firm willing to pay the highest annual fee, called the Timber Rights Fee. In addition there are requirements for a Social Responsibility Agreement with local communities and a forest management plan (GoG 2003:13(2)).

The de facto implementation of the timber rights allocation framework has differed significantly from the de jure regulation. 62 areas have been ratified as TUCs but only 7 of them have been allocated after competitive bidding (Global Witness 2013). In addition, large numbers of TUPs have been allocated to timber firms, not to local communities as stipulated in the legislation. No complete information is available, but for 2001 and 2002 alone, 572 TUPs and SFPs

TABLE 1 Overview of timber right allocation policies in Ghana and their implementation since 1992

\begin{tabular}{|c|c|c|c|c|c|}
\hline Period & 1992-1996 & 1996-2000 & 2000-2004 & 2004-2008 & 2008-2012 \\
\hline $\begin{array}{l}\text { Key policy and } \\
\text { legislative } \\
\text { developments }\end{array}$ & $\begin{array}{l}\text { - Ghana Forest } \\
\text { \& Wildlife } \\
\text { Policy (1994) }\end{array}$ & $\begin{array}{ll} & 1997 \text { Timber } \\
\text { Resources } \\
\text { Management } \\
\text { Act } \\
\text { - } 1998 \text { Timber } \\
\text { Resources } \\
\text { Management } \\
\text { Regulations }\end{array}$ & $\begin{array}{l}2002 \text { Timber Resources } \\
\text { Management (Amend- } \\
\text { ment) Act } \\
\text { - } 2003 \text { Timber Resources } \\
\text { Management (Amend- } \\
\text { ment) Regulations }\end{array}$ & & $\begin{array}{l}\text { Voluntary } \\
\text { Partnership } \\
\text { Agreement } \\
\text { (VPA) between } \\
\text { Ghana and EU }\end{array}$ \\
\hline $\begin{array}{l}\text { De facto imple- } \\
\text { mentation in } \\
\text { forest reserves }\end{array}$ & $\begin{array}{l}\text { Administrative } \\
\text { allocation of } \\
\text { leases }\end{array}$ & $\begin{array}{l}\text { Administrative } \\
\text { allocation of } \\
\text { leases }\end{array}$ & $\begin{array}{l}\text { Primarily administrative } \\
\text { allocation of TUCs }\end{array}$ & $\begin{array}{l}\text { Primarily adminis- } \\
\text { trative allocation of } \\
\text { TUCs and SFPs }\end{array}$ & $\begin{array}{l}\text { Administrative } \\
\text { allocation of TUCs } \\
\text { and SFPs }\end{array}$ \\
\hline $\begin{array}{l}\text { De facto imple- } \\
\text { mentation outside } \\
\text { forest reserves }\end{array}$ & $\begin{array}{l}\text { Administrative } \\
\text { allocation of } \\
\text { leases and permits }\end{array}$ & $\begin{array}{l}\text { Administrative } \\
\text { allocation of } \\
\text { permits }\end{array}$ & $\begin{array}{l}\text { Administrative allocation } \\
\text { of TUPs and SFPs }\end{array}$ & $\begin{array}{l}\text { Administrative } \\
\text { allocation of TUPs } \\
\text { and SFPs }\end{array}$ & $\begin{array}{l}\text { Administrative } \\
\text { allocation of SFPs }\end{array}$ \\
\hline Government* & NDC & NDC & NPP & NPP & NDC \\
\hline
\end{tabular}

*NDC: National Democratic Council; NPP: New Patriotic Party. 
were allocated covering an area of 1.4 million ha (Danso and Opoku 2004). Also, the average size of the SFPs allocated in 2001 and $2002-22.9$ square $\mathrm{km}$ - suggests that far from all permits under this heading can be categorized as "salvage" in accordance with the law. Moreover, anecdotal information collected as part of the present study suggests widespread allocations of TUPs in 2007. The number and extent of permits allocated under this procedure is again not known. With the change of government in 2008 and the Voluntary Partnership Agreement (VPA) between Ghana and EU under the EU Forest Law Enforcement, Governance and Trade (FLEGT) action plan - more on this to follow - TUPs are no longer issued. Contemporary timber rights in Ghana thus consist of TUCs, SFPs and "old" leases and concessions not yet converted to TUCs.

\section{METHODS}

Data collection involved 30 semi-structured interviews carried out in September 2011. 24 interviews were conducted with respondents from 22 timber firms, most of them located in the Ashanti region. The remaining 6 interviews were held with representatives from the FC, the Ministry of Lands, Forestry and Mines, Ghana Timber Millers' Organization (GTMO), and Ghana Timber Association (GTA).

Because no public records are available on timber right holders in Ghana, the selection of timber firms for interviews took place according to the principle of snowball sampling (Fink and Kosecoff 1998). Two snowballs were followed. One took point of departure in a list of timber rights holders in the Ashanti region obtained from the Regional Office of the FC. The second used contacts to large-scale and mediumscale timber firms established through earlier research. During interviews, information and contact details for additional timber rights holders/firms were procured and this helped identify the subsequent respondents.

Based on knowledge of the sector from previous research, a typology of timber right holders in Ghana had been developed beforehand with the aim of having all categories represented in the sample: (i) large firms with long-term, on-reserve timber rights and own processing facilities; (ii) medium scale firms, primarily with short-term (off reserve) timber rights and own processing facilities; (iii) medium scale firms without timber rights and own resource rights; (iv) small scale firms, primarily with short-term, off-reserve timber rights and no or small-scale processing facilities; (iv) smallscale firms with processing and/or logging facilities but no timber rights; (v) individuals/firms that are not engaged in timber production as such but hold timber right(s). Interviews with respondents from categories (i)-(iv) were carried out (Table 2). It proved difficult to schedule interviews with category (v) respondents. This was partly due to reluctance among category (i)-(iv) respondents to share contact details of category (v) respondents and partly due to reluctance of category (v) firms/individuals to participate in interviews. This reluctance was primarily explained with reference to the sensitivity of the timber rights issue.

The interviews focused on how the firms had acquired their present timber rights and - where relevant - on narratives of unsuccessful attempts to acquire timber rights. Issues of relevance to rent-seeking, such as de facto allocation procedures, level of discretion in bureaucratic allocation, the role and relations between firm and government staff and politicians were systematically probed into during interviews. The respondent was typically the Managing Director or General Manager of the firm. Finally, interviews with timber industry organizations and government officials focused on the position, efforts and activities of the organization in relation to timber rights allocation.

All respondents were informed about the purpose of the research prior to the interview and asked for their consent. Respondents were assured anonymity. A digital voice recorder was used during interviews. In instances where the respondent preferred the interview not to be recorded, detailed notes were taken instead. All recorded interviews were subsequently transcribed. Interview transcripts were coded to typologies (bureaucratic corruption, political corruption, lobbying) and actors (small-scale, medium-scale, large-scale firms).

\section{Reflections on methods and validity}

The topic of the research is sensitive which calls for a reflection on the validity of study findings. During interviews, respondents often talked "around the issues", using vague and imprecise phrases. Often activities were narrated as what others were doing and made reference to general issues in the timber sector rather than being presented as own experiences and own behaviour and strategies in relation to timber rights acquisition. During interviews, efforts were made, through probing, to get direct and specific narratives related to the particular person/firm in question, rather than general statements. The study was fairly successful in achieving this. Part of this probing involved cross-referencing observations and confronting interviewees with the narratives of other respondents. The findings presented below suggesting

TABLE 2 Overview of interviewed firms

\begin{tabular}{lccc}
\hline Category of firm & No. of interviewed firms & No. of firms with timber rights & No. of firms with processing facilities \\
\hline Large-scale & 3 & 3 & 3 \\
\hline Medium-scale & 8 & 4 & 8 \\
\hline Small-scale & 11 & 11 & 2 \\
\hline Total & 22 & 18 & 13 \\
\hline
\end{tabular}


distinct patterns and various forms of rent-seeking are considered valid and credible primarily with reference to the consistency in the narratives.

As mentioned, no interviews have been conducted with category (v) respondents. For this group, we rely on the narratives from the timber firms who subsequently negotiate agreements with them. It would obviously have strengthened the findings to have category (v) respondents, but for the reasons explained above this was not possible. Moreover, the research would have benefitted from additional interviews with bureaucrats, at central and at district level, to gain additional insight in the exchange relations between agents within the State bureaucracy. Also, interviews with politicians such as ministers and members of parliament could have added information on these interactions. Based on the interviews that were conducted with bureaucrats it can, however, be questioned whether this would have provided further insights, because the narratives/insights gained were less rich than those obtained from the interactions with the timber firms.

\section{RESULTS}

\section{Bureaucratic corruption}

The narratives of small- and medium-scale firms point towards a number of practises that are here described under the heading bureaucratic corruption. The medium- and smallscale firms explain that they are primarily applying for TUPs and SFPs. These are primarily short-term (up to 5 years) and in the off-reserves. According to the legal framework, it is the responsibility of the FC to identify suitable areas for allocation of timber rights, to inform and obtain consent from concerned landowners, and advertise the areas for competitive bidding (GoG 1997, GoG 1998, GoG 2002 and GoG 2003). The interviews, however, reveal how the firms are in practice given the responsibility for these tasks, including identification of potential permit areas and negotiations with chiefs and fringe communities "...we pay them [scouts] and send them out and they will go around and they will tell you that on his round he saw some land located here or there..." (Interview no. 3). Respondents also describe how these tasks typically require good relations to bureaucrats with responsibilities in timber right. Such relations are hard to establish without unofficial payments. Small-scale and medium-scale firms describe how they use their contacts in FC to identify an area to apply for "... the way you identify it [the area] is usually in the way you get a hint from somebody in FC..." (Interview no. 10) and some get assistance from the district cartographer "... the cartographer knows all the places, where it is encumbered and where it is not encumbered. So if you approach him, he will tell you that this and this place is ok. . . it is important to know the cartographer..." (Interview no. 20). Respondents explain how unofficial payments to bureaucrats at various levels in the system is a widespread practice to motivate or smooth the process of getting an application through the system ". . .it is their work in the office. It is not the money that you give to them that influences whether you get it [the permit] or not. But that the person is doing these things for you at times you have to give him something..." (Interview no. 4). The payments made are often described as a natural part of interactions with bureaucracy "... As for tips it is natural, it is illegal, but it is natural. In any establishment you sometimes even have to put some money down from your pocket, but they cannot ask anything from you. But for you to motivate them - it is not a bribe - it is a motivation. If you come late in the afternoon you want him to help you because you need the letter, he can stay on and help you and you pay for his lunch or something like that..." (Interview no. 3).

The payments take place in the way that the applicant makes sure that a certain amount is handed over personally to the officer at the given level. This means that passing the application from one person at one level to the next person at the next level requires for the applicant to be present - personally or through a trusted agent - to make sure that the application is taken through and that the right person is "motivated". Particularly the small-scale firms describe how this can be a time and resource demanding exercise - often with an uncertain outcome "... maybe you can go early in the morning and you will not get it and then somebody comes in the evening time and he will get it straight..." (Interview no. 13). In terms of determining the appropriate amount to be paid for a particular service, especially the small- and medium-scale firms describe how this is an unpredictable endeavour ". . . the money that you have to pay to motivate a certain officer to work for you is not a fixed amount, and the officer will never ask for the money. You will just know that this is needed, and you top up the amount paid until they will let you know - indirectly - that it is enough or until you are not able to pay more and everything you have paid so far will be lost. .." (Interview no. 15).

Acquiring timber rights in this way is, however, not only a matter of making sufficiently high unofficial payments at different stages of the process; it is also intimately related to social relations and ties. Many respondents stress how good relations to bureaucrats are essential ". . . they are people that you are going to work with every day so you better have a good relation they are your major stakeholders. They are in power. .." (Interview no. 2). Such relations can be based on a history of acquaintance or working relations established over longer periods of time ". . . because we have been around for a long time we can get things done quicker than someone who has not been around for that long..." (Interview no. 2). In many instances personal links to central level bureaucrats may facilitate the acquirement of the timber right and the administrative application process. As narrated by one respondent: "...I will tell you how [to acquire a resource right]: you have a friend in FC they will help you to find a place. You will make your company and you apply for it and they will give it to you. .." (Interview no. 27).

The medium-scale firms without timber rights describe how they have been discouraged from pursuing timber rights because of the hassle, costs and uncertain outcome of the process. They are instead relying on buying logs from smallscale firms that have managed to access timber rights but 
have no processing facilities: “. . .As it is uncertain whether the unofficial payments for getting a concession will actually give us what we want, and as we learned that we will not get it unless we pay a lot we have decided to continue to work with contractors..." (Interview no. 12). Other firms have decided to leave the timber sector altogether with reference to the unpredictability and need for informal payments.

\section{Political corruption}

For acquiring on-reserve timber rights - in the past leases, now TUCs - large-scale firms describe that connections to politicians and high level bureaucrats are important. The small-scale and medium-scale firms on the other hand describe that they do not have the resources to establish these links and hence do generally not have access to these timber rights. Respondents from the large-scale firms describe how connections need to be established and "groomed" over time. Contributions to election campaigns, financial assistance to overseas education for family members of politicians and provision of luxury vehicles are among the elements that respondents describe as important for maintaining their links with politicians and high level bureaucrats. Respondents also explain that these means are not used in a one-to-one exchange for a particular timber right. They are rather integrated elements of long-standing relationships. They are used to maintain and strengthen the relationship and may sometime in the future materialize in a timber right allocation. Additional means for maintaining relations include activities of a more social nature, e.g. in the form of hosting lunches, dinner parties or field visits with press coverage for politicians when they are visiting the area where the firm resides. The large-scale firms (the directors/owners) have direct relations with key politicians and top bureaucrats, but also make use of representatives/agents. These are persons who are close to the political decision-making and familiar with the "rules of the game" and can represent the firm and engage in day-to-day interactions with politicians and senior bureaucrats in Accra. The representatives are typically former senior bureaucrats or other persons with knowledge of the political decision-making and with a political network.

Apart from relationships between politicians and senior bureaucrats and large-scale firms, respondents also describe processes whereby resource rights are allocated to individuals with no apparent linkages to timber production or forestry, i.e. individuals and firms with no previous timber rights, experiences or equipment, presumably by virtue of being political and/or personal supporters. "... There are two categories: the businesses that have their connections and get steady access to these types of concessions. They are more or less fixed. The individuals who get little permits, they are always changing depending on who is in the position of power and their [political] linkages..." (Interview no. 10). Or as narrated by another respondent: ". . . if you are a member of the party and you give financial support to the campaign or if you make sure that this man will stay in office and then in return you will get a concession. That is the political way..." (Interview no.
17). In the past, this practice presumably involved off-reserve TUPs and SFPs. However, as the resource base is dwindling and off-reserve areas degraded, a new practice has emerged whereby single compartments (approximately $128 \mathrm{ha}$ ) in forest reserves have been allocated as rewards for political support: Respondents describe how this practice has negative influence on the forest management and hence on the state of the forest: "...we see in a lot of areas that they are not applying proper forest management because they give out compartments within a felling [coup] to about 10 different companies. This means that the area will be totally degraded because who is going to put the necessary inputs?" (Interview no. 26).

Timber rights in the hands of a person without skills and equipment only gain value for the holder when sold or subcontracted to a timber firm: ". . . they will get the concession as a repayment for some political favour and then they sell the logs to the contractors..." (Interview no. 24). In some cases, the timber right holder will contact a small-scale firm (logging firm) who will provide felling equipment and carry the operational expenses. In other instances the timber right holder will contact the large scale firms directly and make agreements for $\log$ extraction and further processing "... There are other people who have their concessions or compartments. . .many of them aren't really involved in the timber industry at all, they just got a hold of them through favours to some people in power. . we make an agreement with them we pay them per $m^{3}$..." (Interview no. 10). The large-scale firms even describe how the deals on who is going to buy the logs from the politically allocated compartments are sometimes made during the allocation. "... they know how desperate we are... so they distribute the permits to their friends because they know that we will pay..." (Interview no. 6). In other cases, the timber firms use their connections to FC to acquire information on where allocations have recently been made to individuals not engaged in timber production "... usually they [timber right holders] will call if they know us. Otherwise we are quite close to a lot of the forestry people like [bureaucrat] and they will let us know that this or that compartment has been allocated so and so, we know the people there are not going to work in it, so maybe it would be a good idea to contact them and see if you can come to an agreement..." (Interview no. 10). These deals require payments and transaction costs "... you have to buy from him before you can feed your mill... because of the political system. . this middle person has to be here. So that he gets the money..." (Interview no. 24). "... for example me [] 70\% of my logs are coming from agreements with contractors that have their TUCs... most of them have been allocated in political ways. .." (Interview no. 27).

\section{Lobbying}

The large-scale firms describe how they are able to organize to discuss their concerns and getting their message through to bureaucrats and political decision makers. As example, the respondents mention that through collective action and 
persistent resistance coordinated by the GTMO the timber industry has been successful in halting plans to raise stumpage fees by more than 200 per cent ${ }^{2}$ " ... because of our engagement, the government accepted not to raise the stumpage so the industry can also have some advantage and they will be able to export at world market prices. .." (Interview no. 19). Respondents also narrate how they have been successful in lobbying for a reduction of the export levies with reference to their adverse effects on the profitability and further development of the timber industry, including jobs, in Ghana. Consequently, the export levies have been reduced from $3 \%$ to $1.5 \%$ of the export value. On the question of timber rights allocation, including competitive bidding and transparency in allocation processes, there appears to be no collective industry stance and firms are primarily engaged in fighting for themselves: ". . . the issues on allocations we have more or less accepted, it is very difficult to control. You may reach some of the people in power now when they change, there comes another battle..." (Interview no. 10). Another respondent remarked: "... Most of the time everyone is fighting for himself... I may go and fight for the organization but I will also go behind and fight for one concession for me. .." (Interview no. 27).

As would be expected, the results suggest that collective action is more pronounced among the large-scale firms (they are few), whereas collective action among the small- and medium-scale firms (they are many) is less developed.

\section{DISCUSSION}

\section{Discussion of empirical findings}

Figure 1 summarizes the findings of the study in a resource flow chart developed with inspiration from Khan and Sundaram (2000). It shows the various actors (politicians, bureaucrats, large-scale firms, medium-scale firms, small-scale firms and individuals) and the flows of resources (timber rights rents) and payments (bribes) and services/support.

The study suggests that bureaucratic corruption exists alongside political corruption. The apparent co-existence of bureaucratic and political corruption supports the argument of Fjeldstad and Isaksen (2008) that political corruption with no bureaucratic corruption is rare. The study did not engage in a detailed investigation to further illuminate or understand the linkages between the bureaucratic and political corruption, but it is identified as a topic for further research.

Much of what has been described under the heading bureaucratic corruption are forms of everyday practices between bureaucrats and firms, embedded in cultural practices and norms (tradition, friendship, professional ties etc.), and by many of the respondents not even considered as corruption. Payments or other services are an inherent part of the interactions between government officials and private actors and as argued by e.g. Scott (1972) and Khan and Sundaram (2000) the distinction between gifts of appreciation

FIGURE 1 Resource flows in the timber sector in Ghana

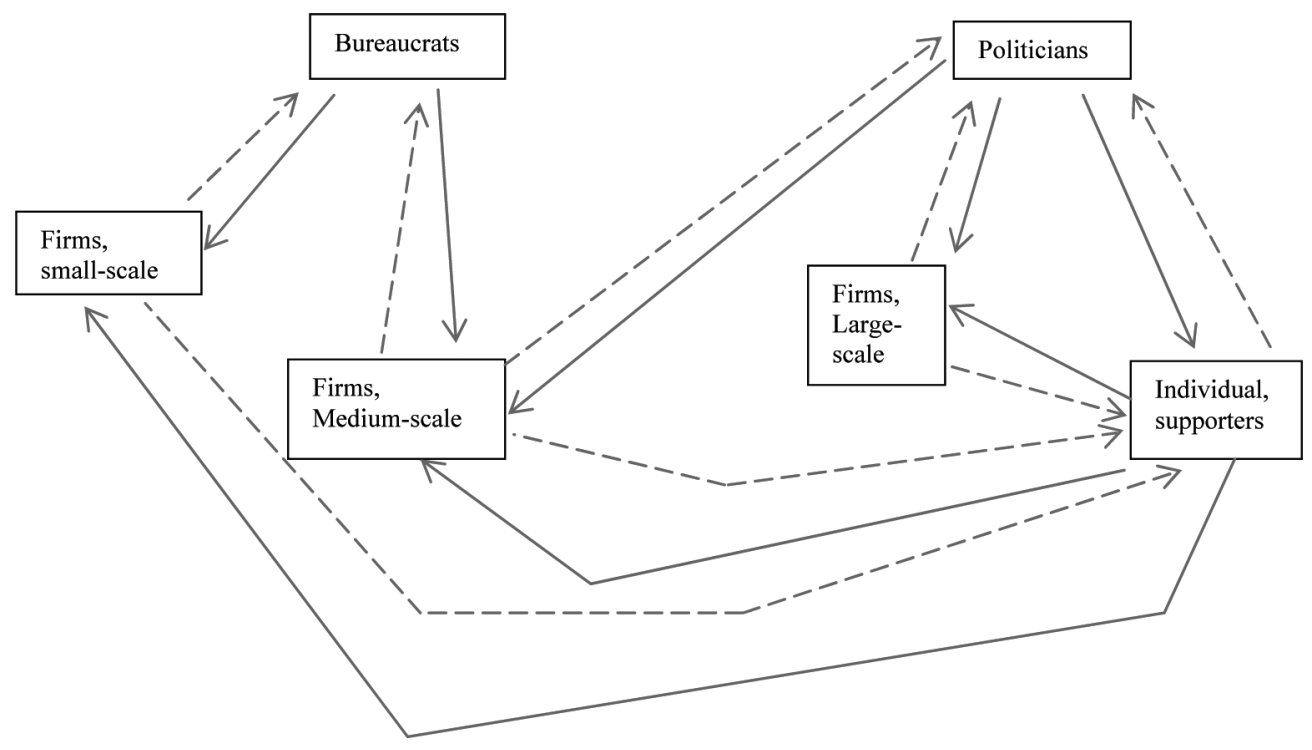

Means of exchange:

Timber rights:

Payment, cash or kind: $----->$

2 The stumpage fees have been held at constant nominal values since 2003. After the conclusion of the research, the stumpage fee rates have been increased (March 2014). 
and bribes can be hard to make. What is of particular interest here, though, is the fact that administrative practices appear to have been adopted from the de jure legislation in ways that create room for bureaucratic discretion and demands or expectations for informal payments. These practices are primarily described by the small-scale and medium-scale firms in their pursuit of TUPs and SFPs, and primarily in the off-reserves. To what extent these practices and allocations also involve payments to senior bureaucrats and/or politicians, i.e. political corruption, is not clear from the study. The respondents clearly focused on the interactions with lower level bureaucrats, but this could be a result of the sensitive nature of the matter.

The study also documents political corruption, i.e. the allocation of timber rights in exchange of personal favors and/or political support. Two different models emerge from the study. The study documents that the large-scale, wellestablished timber firms nurture relations with politicians and high-level bureaucrats around timber rights. But there are also firms and individuals without any track record in the forest sector who are granted timber rights, presumable as reward for political support. These timber rights are subsequently re-sold or sub-contracted to "real" timber firms. The political corruption is primarily related to allocation of timber rights in the forest reserves which are longer term and generally more profitable than the off-reserve resources. It is therefore likely that larger rent flows are tied to political corruption as compared to bureaucratic corruption.

The exchange relations between politicians and their clients, whether they are (large-scale) timber firms or individual, political supporters, are collusive, which suggest that none of these groups are inclined to support institutional changes in timber right allocation. Following the arguments of Khan and Sundaram (2000), the 1997 TRMA, the 1998 TRMR and their amendments in 2002 and 2003 have had limited success (poor implementation), precisely because the most powerful and influential actors have resisted rather than supported their implementation because these institutional changes go against their interests. Study findings document that in spite of attempts to change this institutional practice, timber right allocations continue to take place in a centralized and discretionary manner.

The findings of the study provide an example of "rent seizing" (Ross 2001). In the Ghana case, all the way since the 1962 Concessions Act (GoG 1962) politicians and senior bureaucrats have had the direct, exclusive and discretionary control over timber right allocations and the price to be paid for standing timber by the timber right holder. It is noted that it is exactly the low official fees that create the high resource rents and thus make timber rights an object for patronage and rent-seeking activities (Hansen and Lund 2011).

Finally, the study suggests that timber rights allocation is not a suitable issue for organization of collective action because the firms have strong individual interests in having as large a share of the cake as possible, not least in a situation with a dwindling resource base. However, as described, the rents in the system are contingent on the maintenance of low, official fees on timber, and here the firms have a common interest, and consequently have been able to organize collective action, and quite successfully.

\section{Consequences of observed rent-seeking practices}

The empirical focus of this study has been on the rent-seeking processes shaping current timber right allocation and less on the consequences (outcome) of these. Still, the findings of the study point towards consequences for involved firms in the form of reduced levels of investments and efficiency and for society in the form of reduced benefit sharing and resource degradation. The findings suggest that it is profitable, or indeed necessary, for the firms to employ resources on rentseeking rather than on investments in productive firm capital. Alongside substantial transaction costs associated with doing business, this allegedly leads to reduced profit margins, limits the incentive to undertake new efficiency enhancing investments and drives investments away from the sector (Lambsdorff 2008, Palmer 2005, Svensson 2005).

In terms of benefit distribution, the current practise of timber right allocation, including keeping fees at a low level, cause rents to be skewed towards political actors, their supporters, and, probably to a lesser degree, the bureaucrats involved in the allocation processes. This happens at the expense of the constitutional beneficiaries of timber revenues, i.e. District Assemblies, Traditional Councils, Stools and the FC. This again has negative implications for the financial resources available for management and governance of the forest. Also the allocation of short-term timber rights to single compartments in forest reserves contributes to forest degradation because it compromises sustainable forest management practices. Finally, the current practices raise doubts about the commitment given by the state to sustainable forest management. The timber right allocation process is important in this regard as it can be seen as the first step in a chain of procedures for responsible resource management. If signals are sent that this first step can be evaded, it sends strong signals as to how to go about the subsequent steps.

\section{The way forward: measures to address rent-seeking}

In 2008, Ghana signed a Voluntary Partnership Agreement (VPA) on Forest Law Enforcement, Governance and Trade (FLEGT) with the European Commission. The aim is to curb illegal logging and strengthening forest governance through a Timber Legality Assurance System (TLAS) and associated institutional reforms. The TLAS is not yet fully operational, and reforms not implemented, but developments associated with the VPA implementation have already had a positive effect on curbing the rent-seeking practises related to timber rights allocations. First, as described, the VPA has resulted in a stop of allocation of TUPs. Second, the VPA has resulted, for the first time, in the release from the FC of a complete list of allocated timber rights (Global Witness 2013). The accuracy of the list is debated (FC 2013) but at least this is a 
positive start. These observations echo other studies that have pointed at role of the VPA in facilitating increased level of transparency and broader participation (Beeko and Arts 2010, Owusu 2009, Bollen and Ozinga 2013). The potential of the VPA in bringing about permanent changes in the current practises and incentive structures, obviously rely on the full implementation of the TLAS and roll out of the envisaged reforms. An additional aspect that may add positively in addressing rent-seeking practises is the degraded nature of the timber resource. Partly as a result of past rent-seeking practises, the timber resources in Ghana are highly degraded (Hansen and Treue 2008, Hawthorne 2012) and the rents that can be extracted from the timber resource are dwindling which makes the resource less interesting for political corruption in the form of patron-client relations and reforms more likely.

Apart from the efforts under the VPA, the anti-corruption literature suggests a number of measures to curb bureaucratic and political corruption. Suggested measures to address bureaucratic corruption include: (i) increased penalties, (ii) increased official salaries, (iii) simplification of regulations and bureaucratic procedures, (iv) privatization, (v) meritocratic hiring and promotion, and (vi) staff rotation (Lambsdorff 2008, Fjeldstad and Isaksen 2008). These may also be considered in the forest sector of Ghana, but with reference to the present study, the cultural embeddedness and everyday nature of the corruption challenges practical implementation of these measures. On political corruption key measures are typically: (i) institutional reforms promoted by civil society, the private sector and the media, (ii) increased competition for political mandates and (iii) strengthening of the independence and quality of the judicial service (Lambsdorff 2008). They all focus on increased transparency and accountability of politicians and high-level bureaucrats (Kolstad and Wiig 2009). The first measure links back to the VPA and its goal of institutional reforms. Similar objectives of broad-based institutional reforms are stated in Ghana's Readiness Plan for REDD+ (FC 2010). The two latter measures are more general, long-term measures, not sector-specific, and hence need to be implemented as part of large, general governance reforms, and less likely to influence rent-seeking practices in the forest sector in the short-term.

\section{CONCLUSION}

The study has documented that timber rights allocation in Ghana involves both bureaucratic and political corruption. The former is primarily mentioned by small- and mediumscale timber firms seeking timber rights outside the forest reserves and appears to relate - at least partly - to everyday practises of "doing business" rather than direct demands for bribes. The evidence for political corruption is provided by the large-scale firms who describe their long-standing relationships with politicians and senior bureaucrats involving exchange of timber rights for political support and/or personal material benefits, i.e. patron-client relationships. The study also documents a second type of political corruption whereby individuals or firms outside the timber sector are awarded timber rights presumably as a reward for political support. These timber rights are subsequently transferred to timber firms with the required expertise and equipment. The study thus documents bureaucratic corruption taking place alongside political corruption, but it does not hold information to illuminate or understand the linkages between the two. This could be a topic for further research.

Lobbying appears not to be of direct relevance in timber rights allocation or the de jure policies prescribing it, because the firms have large individual material interests in getting access to as many areas as possible. However, collective action is prominent in relation to the political/administrative setting of the level of the harvesting fees (the stumpage fee) where the firms have lobbied successfully for their freeze. The low level of fees is what in essence creates the rents and drives the documented rent-seeking activities.

An array of measures can potentially be considered to curb corruption in relation to timber rights allocation. The Voluntary Partnership Agreement between Ghana and the EU under the Forest Law Enforcement, Governance and Trade action plan is believed to be an important step forward in curbing rent-seeking in the timber sector because it has increased, and is likely to increase further if fully implemented, the transparency of timber rights allocation. In addition, the degraded nature of the timber resources is likely to contribute to reduce rent-seeking and facilitate the reform process.

\section{ACKNOWLEDGEMENTS}

Special thanks go to the respondents from the participating timber firms and sector organizations. We also acknowledge the comments and suggestions received from two anonymous referees which helped to shape the final version of the manuscript. We acknowledge support from the Danish Consultative Research Committee for Development Research under grant "Corporate social responsibility: the case of forestry in Ghana (DFC project no. 10-097-LIFE) and the Performance Contract between Danida and the Faculty of Life Sciences, University of Copenhagen (UM 104.M.87).

\section{REFERENCES}

AGRELL, P.J. and GAUTIER, A. 2012. Rethinking regulatory capture. In: Recent advances in the analysis of competition policy and regulation, eds. J.E Harrington Jr and Y. Katsoulacos, Edward Elgar Publishing Inc. 375 p.

AMANOR, K.S. 1996. Managing trees in the farming system. The perspectives of farmers. Forestry Department, Accra, Ghana, 202 p.

ARYEETEY, E., AYEE, J.R.A, NINSIN, K.A. and BARDHAN, P. 2007. The politics of land tenure reform in Ghana: From the Crown Lands Bills to the Land Administration Project. Technical Publication No. 71. Institute of Statistical, Social \& Economic Research (ISSER), University of Ghana, Legon, Ghana. 83 p. 
BARDHAN, P. 1997. Corruption and development: a review of issues. Journal of Economic Literature 35(3): 132046.

BATES, R.H. 1981. Markets and states in tropical Africa. The political basis of agricultural policies. University of California Press, Berkley and Los Angeles, United States of America. $178 \mathrm{p}$.

BAYART, J-F. 2009. The state in Africa. The politics of the belly. Polity Press, Cambridge. 370 p.

BEEKO, C., ARTS, B. 2010. The EU-Ghana VPA: a comprehensive policy analysis of its design. International Forestry Review 12: 221-230.

BLUNDO, G., DE SARDAN, J-P.O., ARIFARI, N.B., ALOU, M.T. 2006. Everyday corruption and the state. Citizens and public officials in Africa. ZED Books, London. $298 \mathrm{p}$.

BÓ, E.D. 2006. Regulatory capture: a review. Oxford Review of Economic Policy 22(2): 203-25.

BOEHM, F. 2007. Regulatory capture revisited-lessons from economics of corruption. Internet Centre for Corruption Research, Working Paper, July 2007. 30 p.

BOLLEN, A., OZINGA, S. 2013. Improving forest governance. A comparison of FLEGT VPAs and their impact. FERN, Brussels. 52 p.

BONI, S. 2005. Clearing the Ghanaian forest: Theories and practices of acquisition, transfer and utilisation of farming titles in the Sefwi-Akan area. Institute of African Studies, University of Ghana, Legon, Accra, 271 p.

BROAD, R. 1995. The Political Economy of Natural Resources: Case Studies of the Indonesian and Philippine forest sectors. The Journal of Developing Areas 29(3): 317-40.

COLLIER, P. 2008. Laws and Codes for the resource curse. Yale Human Rights and Development Law Journal 11: 9-28.

DANSO, E. and OPOKU, K. 2004. Legality and impacts of forest utilisation permits in Ghana. International Institute for Environment and Development (IIED), London, 44 p.

FINK, A. and KOSECOFF, J. 1998. How to conduct surveys. A step-to-step guide. Second edition. Sage Publications Inc., Thousand Oaks. 200 p.

FJELDSTAD, O.-H. and ISAKSEN, J. 2008. Anti-corruption reforms: challenges, effects and limits of World Bank support. Background paper to public sector reform: What works and why. An IEG Evaluation of World Bank Support. IEG Working Paper 2008/7. 92 p.

FC 2010. Readiness preparation proposal Ghana. http://www. forestcarbonpartnership.org/sites/forestcarbonpartnership. org/files/Documents/PDF/Feb2010/Final_version_Ghana_ R-PP_with_disclaimer_21810.pdf (Accessed 27 August 2014).

FC 2013. Forestry Commission ravishes Global Witness Report. http://www.fcghana.org/news.php?news=67 (Accessed 20 August 2014).

GLOBAL WITNESS 2013. Three quarters of Ghana's logging permits could break Europe's new timber law. http://www.globalwitness.org/ghanapermits (Accessed 19 August 2014).
GOVERNMENT OF GHANA (GOG) 1962. Concessions Act. The Government Printing Department, Accra.

GOVERNMENT OF GHANA (GOG) 1992. The Constitution of the Republic of Ghana 1992. Tema Press of Ghana Publishing Corporation, Tema.

GOVERNMENT OF GHANA (GOG) 1994. Forest and Wildlife Policy. Ministry of Lands and Forestry. Forestry Commission, Ministry of Lands and Forestry. http://www. fcghana.org/library_info.php?doc=43\&publication:Fores $\mathrm{t} \% 20 \& \% 20 \mathrm{Wildlife} \% 20$ Policy\&id=15 (Accessed 12 April 2013).

GOVERNMENT OF GHANA (GOG) 1997. Timber Resources Management Act 1997. Act 547. Ministry of Lands and Forestry. Forestry Commission, Ministry of Lands and Forestry. http://www.fcghana.org/library_info. php?doc $=45 \&$ publication:Timber Resource Management Act, 1997 - Act 547\&id=15 (Accessed 12 April 2013).

GOVERNMENT OF GHANA (GoG) 1998. Timber Resources Management Regulations. L.I. 1649. Forestry Commission, Ministry of Lands and Forestry. http://www.fcghana. org/library_info.php?doc=46\&publication:L.I. 1649 Timber Resources Management Regulations, 1998\&id=15 (Accessed 12 April 2013).

GOVERNMENT OF GHANA (GoG) 2002. Timber Resources Management (Amendment) Act. Act 617. http://www. fcghana.org/library_info.php?doc=47\&publication:Timber Resources Management Act 617 (Amendment) Act, 2002\&id=15 (Accessed 12 April 2013).

GOVERNMENT OF GHANA (GoG). 2003. Timber Resources Management (Amendment) Regulations, L.I. 1721. Forestry Commission, Ministry of Lands and Forestry. http://www.fcghana.org/library_info.php?doc= 48\&publication:L.I.\%201721\%20Timber\%20Resources $\% 20$ Management\%20(Amendment) (Accessed 12 April 2013).

HANSEN, C.P., TREUE, T. 2008. Assessing illegal logging in Ghana. International Forestry Review 10(4): 573-590.

HANSEN, C.P. and LUND, J.F. 2011. The political economy of timber taxation: The case of Ghana. Forest Policy and Economics 13: 630-41.

HAWTHORNE, W.D., SHEIL, D., AGYEMAN, V.K., JUAM, M.A., MARSHALL, C.A.M. 2012. Logging scars in Ghanaian high forest. Towards improved models for sustainable production. Forest Ecology and Management 271: 27-36.

GRINDLE, M.S. 1989. The new political economy. Positive economics and negative politics. Policy, Planning and Research Working Papers, No. 304. The World Bank, Washington DC. 70 p.

HACKETT, S.C. 2001. Environmental and natural resources economics. Theory, policy and the sustainable society. Second edition. M.E. Sharpe Inc., New York. 475 p.

JAIN, A.K. 2001. Corruption: A review. Journal of Economic Surveys 15(1): 71-121.

KASANGA, K. and KOTEY, N.A. 2001. Land management in Ghana: Building on tradition and modernity. International Institute for Environment and Development, London. 42 p. 
KHAN, M.H. and SUNDARAM, J.K. 2000. Rents, rentseeking and economic development: theory and evidence in Asia. Cambridge University Press. 338 p.

KOLSTAD, I. and SøREIDE, T. 2009. Corruption in natural resource management: implications for policy makers. Resources Policy 34: 214-226.

KOLSTAD, I. and WIIG, A. 2009. Is transparency the key to reducing corruption in resource-rich countries? World Development 37(3): 521-532.

LAMBSDORFF, J.G. 2008. The institutional economics of corruption and reform. Cambridge University Press. $286 \mathrm{p}$.

LIPSKY, M. 2010. Street-level bureaucracy: dilemmas of the individual in public services. Russel Sage Foundation, New York, updated edition. 275 p.

ODURO, K.A., MOHREN, G.M.J., AFFUM-BAFFOE, K., KYEREH, B. 2014. Trends in timber production systems in the High Forest Zone of Ghana. International Forestry Review 16(3): 289-300.

OWUSU, B. 2009. The dynamics of multi-stakeholder processes in the negotiation of voluntary partnership agreement in Ghana. M.Sc. Thesis: Communication and
Innovation Studies. Wageningen University - Department of Social Sciences, August 2009. 143 p.

ROSS, M.L. 2001. Timber booms and institutional breakdown in Southeast Asia. Cambridge University Press. $237 \mathrm{p}$.

SCHLEIFER, A. and VISHNY, R.W. 1993. Corruption. The Quarterly Journal of Economics 108(3): 599-617.

SCOTT, J. 1969. The analysis of corruption in developing nations. Comparative Studies in Society and History 11(3): 315-341.

SCOTT, J.C.1972. Comparative Political Corruption. Prentice-Hall Inc., New Jersey. 166 p.

SMITH, J., OBIDZINSKI, K., SUBARUDI and I. SURAMENGGALA. 2003. Illegal logging, collusive corruption and fragmented governments in Kalimantan, Indonesia. International Forestry Review 5(3): 293-302.

STIGLER, G.J. 1971. Theory of economic regulation. The Bell Journal of Economics and Management Science, 2(1): 3-21.

SVENSSON, J. 2005. Eight questions about corruption. Journal of Economic Perspectives 19(3): 19-42.

WINTER, S.C. and NIELSEN, V.L. 2010. Implementering af politik (policy implementation). Academica. 232 p. 